\title{
Grafting Vinyl Monomers onto Modified Cellulose: Potassium Peroxydiphosphate-Induced Graft Copolymerization of Methyl Methacrylate onto Oxidized Cellulose
}

\author{
Munmaya Kumar MishrA, Subasini LenKA, \\ and Atanu Kumar TRIPATHY
}

78A, Kalpana Area, Bhubaneswar-751 014, Orissa, India.

(Received May 9, 1980)

\begin{abstract}
Cotton cellulose was independently oxidized with sodium metaperiodate, potassium dichromate-sulfuric acid, and potassium dichromate-oxalic acid. The various modified celluloses so-obtained were grafted with methyl methacrylate using peroxydiphosphate as the initiator. It was found that the initiation characteristics of the cellulose samples vary widely with the oxidizing agent used. The various factors which affect the graft uptake, such as the substrate, [peroxydiphosphate], [methyl methacrylate], $\left[\mathrm{H}_{2} \mathrm{SO}_{4}\right.$ ], temperature, and solvent were studied. Also a determination of the molecular weight and elucidation of the reactions involved in initiation of grafting were undertaken.
\end{abstract}

KEY WORDS Sodium Metaperiodate-Oxidized Cellulose / Potassium Dichromate-Sulfuric Acid-Oxidized Cellulose / Potassium DichromateOxalic Acid-Oxidized Cellulose / Unmodified Cellulose / Peroxydiphosphate / Methyl Methacrylate / Grafting / Viscosity / Peroxide / Oxyanion /

Recently, peroxydisulphate has been extensively used as a water-soluble initiator for emulsion polymerization. ${ }^{1}$ Persulphate alone or as a part of redox system has been used as an initiator for grafting onto wool. ${ }^{2-4}$ Extensive oxidation studies $^{5,6}$ have been carried out by persulphate. Ikada, Nishizaki, and Sakurada ${ }^{7}$ have studied the oxidation and graft-copolymerization reaction of poly(vinyl alcohol) by persulphate ions. Peroxydiphosphate (PP), which is isoelectronic and isostructural ${ }^{6,8}$ with peroxydisulphate received little attention till Edwards and coworkers ${ }^{9-12}$ recognised this ion as a free-radical initiator. Recently, Hariharan and Meenakshi ${ }^{13}$ reported the polymerization of vinyl monomers using this ion as the initiator.

The graft polymerization of vinyl monomers onto cellulose xanthate using $\mathrm{H}_{2} \mathrm{O}_{2}{ }^{14}$ as initiator, phosphorylated cellulose using $\mathrm{Fe}^{2+}-\mathrm{H}_{2} \mathrm{O}_{2}{ }^{15}$ redox system, cyanoethylated cellulose using $\gamma$-irradiation, ${ }^{16}$ has been reported. The ceric-ion method has also been used for graft polymerization onto partially-carboxymethylated cellulose,${ }^{17}$ acrylami- domethylated cellulose and carbamoylethylated cellulose,${ }^{18}$ acetylated cellulose, ${ }^{19}$ cross-linked cellulose,${ }^{20}$ oxidized cellulose, ${ }^{21}$ and cellulose bearing sulphur-containing groups. ${ }^{22}$ Very recent work shows the feasibility of using dimethylanilinebenzyl chloride mixture for the initiation of graft polymerization of methyl methacrylate onto partially-carboxymethylated cotton. ${ }^{23}$

Peroxydiphosphate alone or coupled with organic substrate has been used for graft polymerization onto wool ${ }^{24,25}$ and silk. ${ }^{26,27}$

The present work deals with the graft polymerization of methyl methacrylate onto oxidized cellulose for the purpose of finding (a) the feasibility of this system to initiate grafting, (b) the factors affecting the magnitude of polymerization, and (c) its molecular-weight determination.

\section{EXPERIMENTAL}

Egyptian cotton slivers were purified by a mild alkaline scouring $(2 \% \mathrm{NaOH}$ and $0.2 \%$ wetting agent, based on weight of material) for $5 \mathrm{~h}$ at $110^{\circ} \mathrm{C}$ 
and $6-10 \mathrm{lb} \mathrm{in}^{-2}$ using a liquor ratio of $10: 1$.

\section{Periodate-Oxidized Cellulose}

The purified cellulose was immersed in an aqueous solution of sodium metaperiodate $(0.01$ mol $1^{-1}$ ) at $30^{\circ} \mathrm{C}$ for $24 \mathrm{~h}$, maintaining a liquor ratio of $50: 1$.

\section{Potassium Dichromate-Sulfuric Acid-Oxidized Cellu- lose}

Oxidation of the purified cellulose was carried out with $0.1 \mathrm{~N}$ potassium dichromate and $0.2 \mathrm{~N} \mathrm{H}_{2} \mathrm{SO}_{4}$ at $30^{\circ} \mathrm{C}$ for $24 \mathrm{~h}$ using a liquor ratio of $50: 1$.

\section{Potassium Dichromate-Oxalic Acid-Oxidized Cellu- lose}

Purified cellulose was steeped in an aqueous solution containing $2 \mathrm{~N}$ oxalic acid and $2 \mathrm{~N}$ potassium dichromate for $4 \mathrm{~h}$ at $30^{\circ} \mathrm{C}$ using a liquor ratio of $50: 1$.

\section{Isolation of Grafted Poly(methyl methacrylate) PMMA}

Separation of the grafted polymer from the grafted fibres was carried out by two-step $\mathrm{H}_{2} \mathrm{SO}_{4}$ digestion technique. The grafted cellulose $(0.5$ gram of cellulose) was digested with $25-30 \mathrm{~N} \mathrm{H}_{2} \mathrm{SO}_{4}$ $(35 \mathrm{ml})$ for 30 minutes at $80-100^{\circ} \mathrm{C}$. The partlydigested residues were filtered off the solution. Again, digestion was allowed to proceed for $24 \mathrm{~h}$ at $80-110^{\circ} \mathrm{C}$ in a $100 \mathrm{ml}$ flask equipped with a reflux condenser and the residue was washed with boiling water and then dried.

The residue $(0.1 \mathrm{~g})$ was dissolved in ethyl acetate
$(3 \mathrm{ml})$ and precipitated by cold methanol and dried.

Methyl methacrylate (MMA) was washed with a $5 \% \mathrm{NaOH}$ solution, dried with anhydrous $\mathrm{Na}_{2} \mathrm{SO}_{4}$, and distilled under reduced pressure before use.

Peroxydiphosphate (PP), sodium metaperiodate, potassium dichromate, $\mathrm{H}_{2} \mathrm{SO}_{4}$, oxalic acid, and all solvents used were of ( $\mathrm{Ar}$ grade $\mathrm{BDH})$.

The grafting reactions were carried out in pyrex vessels having inlet and out-let tubes. Nitrogen was used to deaerate the experimental system which was freed from oxygen by its passing through Fieser's solution. 2-Ethoxy ethanol was used as monomer solubilizer.

The intrinisic viscosity was calculated by using a single point method for poly(methyl methacrylate) as done by Valles et al. ${ }^{28}$ The molecular weight was obtained from the equation, ${ }^{29}$

$$
[\eta]=9.6 \times 10^{-5} M_{w^{0}}^{-0.69}
$$

\section{Graft Polymerization Procedure}

Conditioned cellulose samples $(0.2 \mathrm{~g})$ were steeped in $20 \mathrm{ml}$ of solution containing known concentrations of $\mathrm{PP}, \mathrm{MMA}$, and $\mathrm{H}_{2} \mathrm{SO}_{4}$. The stoppered flask was kept in a thermostatted water bath for periods varying from $1 \mathrm{~h}$ to $4 \mathrm{~h}$. During the reaction, the cellulosic material was kept well immersed in the solution. After completion of the desired reaction time, the material was taken out, washed with water, dried and then repeatedly Soxhlet extracted with benzene, dried in an oven and weighed. The percentage of graft uptake and $\%$ homopolymer was calculated as follows.

$$
\begin{aligned}
& \% \text { Graft uptake }=\frac{\text { Dry wt of grafted sample }- \text { dry wt of original sample }}{\text { Dry weight of original sample }} \times 100 \\
& \% \text { Homopolymer }=\frac{\text { Dry weight of homopolymer }}{\text { Weight of monomer }} \times 100
\end{aligned}
$$

\section{RESULTS AND DISCUSSION}

Oxidation of cellulose results in the formation of different functional groups on its molecule. Among these groups are alkali-sensitive reducing groups, enediol groups, carboxyl groups, and lactones. The carboxyl groups are formed in different positions of the anhydroglucose units of cellulose macromolecules. The three hydroxyl groups on each glucose moiety in the polymer chain are subject to oxidation according to the following general scheme. The site of grafting is still controversial. Some indications are that it may occur at the hemiacetal oxygen (the polymeric link), and also at adjacent hydroxyl units, 

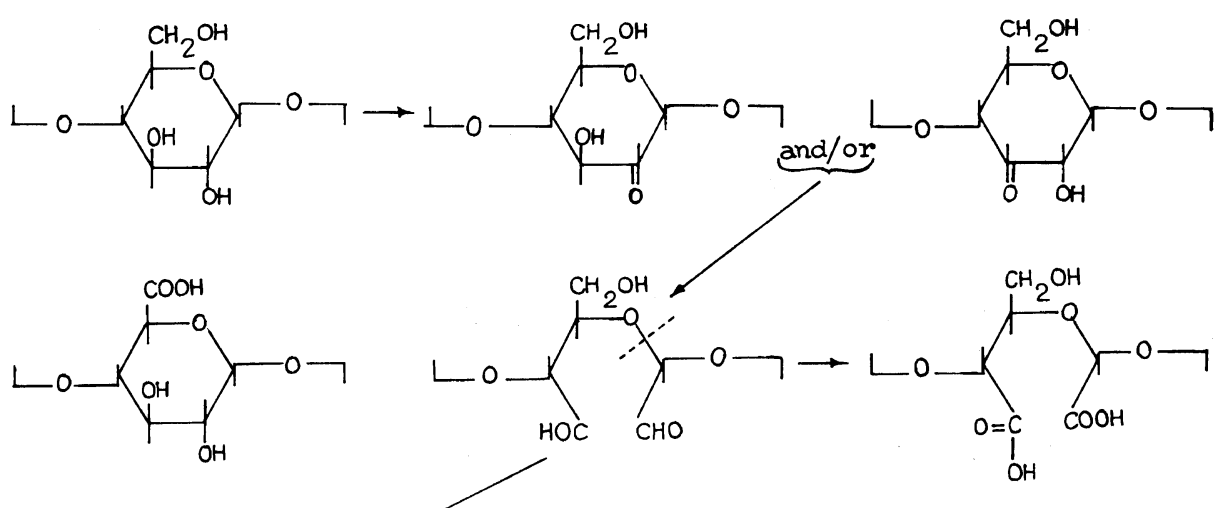

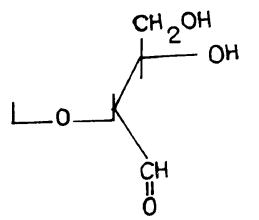

possibly by oxidation of the $\mathrm{OH}$ group. ${ }^{30}$ Grafting on cellulose is also affected by the presence of carboxyl and aldehyde groups. ${ }^{31}$

In the presence of acid, peroxydiphosphate decomposes as shown below. ${ }^{8,32}$ Free radicals such as $\mathrm{H}_{2} \mathrm{PO}_{4} \cdot$, $\cdot \mathrm{OH}$ and $\mathrm{PO}_{4}^{-} \cdot$, produced during the reaction as shown below interact with the groups present in the cellulose macromolecule to produce macroradicals which initiate the grafting.

$$
\begin{aligned}
& \mathrm{H}_{2} \mathrm{P}_{2} \mathrm{O}_{8}^{2-}+\mathrm{H}^{+} \rightleftharpoons \mathrm{H}_{3} \mathrm{P}_{2} \mathrm{O}_{8}^{-} \\
& \mathrm{H}_{3} \mathrm{P}_{2} \mathrm{O}_{8}^{-} \stackrel{\text { Slow }}{\longrightarrow} \mathrm{H}_{2} \mathrm{PO}_{4} \cdot+\mathrm{HPO}_{4}^{-} \cdot \\
& \mathrm{H}_{2} \mathrm{PO}_{4} \cdot+\mathrm{H}_{2} \mathrm{O} \longrightarrow \mathrm{H}_{3} \mathrm{PO}_{4}+\cdot \mathrm{OH} \\
& \mathrm{HPO}_{4}^{-} \cdot+\mathrm{H}_{2} \mathrm{O} \rightleftharpoons \mathrm{H}_{2} \mathrm{PO}_{4}^{-}+\cdot \mathrm{OH}
\end{aligned}
$$

i. Initiation:

$$
\begin{aligned}
& \sim \text { Cell-OH } \stackrel{k_{\mathrm{i}}}{\longrightarrow} \sim \text { Cell-O. } \\
& \sim \text { Cell-O }+\mathrm{M} \stackrel{k_{\mathrm{i}}{ }^{1}}{\longrightarrow} \sim \text { Cell-OM } .
\end{aligned}
$$

ii. Propagation:

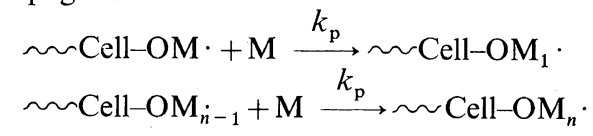

iii. Termination:

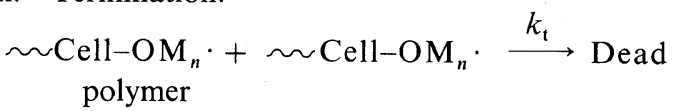

$\sim$ Cell- $\mathrm{OM}_{n} \cdot+$ Initiating radicals $\stackrel{k_{\mathrm{t}}{ }^{1}}{\longrightarrow}$ Dead polymer

where $\sim$ Cell-OH represents the reactive group in the cellulosic material, $\mathrm{M}$ is the vinyl monomer, $\sim$ Cell-O $\cdot$ and $\sim$ Cell-OM $\cdot$ are the corresponding radicals, $k_{\mathrm{i}}, k_{\mathrm{i}}{ }^{1}, k_{\mathrm{p}}, k_{\mathrm{t}}$, and $k_{\mathrm{t}}{ }^{1}$ are rate constants.

\section{Nature of the Substrate}

The plots of the \% graft uptake with different lengths of time are shown in Figure 1. It is seen in Figure 1 that grafting proceeds at a high rate. The rate of grafting follows the order, potassium dichromate-oxalic acid-oxidized cellulose $>$ potassium dichromate-sulfuric acid-oxidized cellulose $>$ unmodified cellulose $>$ sodium metaperiodateoxidized cellulose. The reaction for this is not yet clear and a detailed characterization study of the graft copolymerization products will be necessary.

This indicates that the oxidized state of cellulose varies widely with the oxidizing agent used, and such variation is probably responsible for the characteristic behaviour of each sample during polymerization.

Dependence of $\%$ Graft Uptake on Peroxydiphosphate Concentration

Figure 2 shows the graft uptake as a function of peroxydisphosphate concentration. The concentration range studied is from $50 \times 10^{-4} \mathrm{moll}^{-1}$ to 


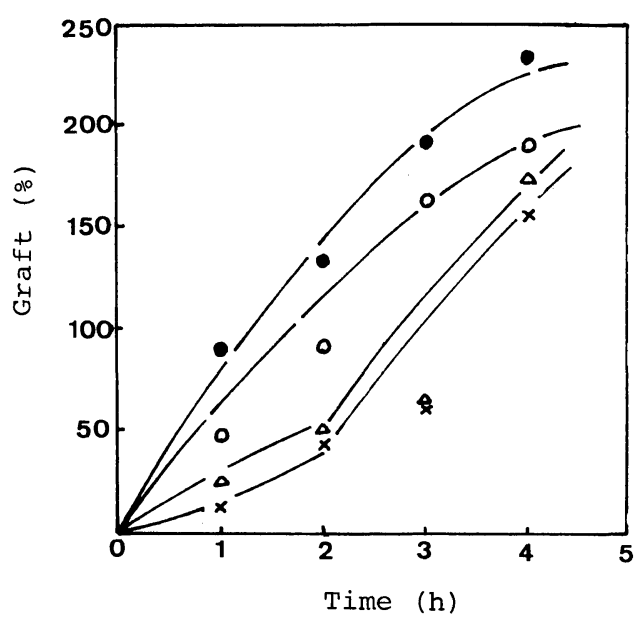

Figure 1. Nature of the substrate: [PP], $80 \times 10^{-4}$ moll ${ }^{-1} ;$ [MMA], $46.94 \times 10^{-2} \mathrm{moll}^{-1} ;\left[\mathrm{H}^{+}\right], 0.148$ mol1 $1^{-1}$; temp, $70^{\circ} \mathrm{C} ; \mathrm{M}: \mathrm{L}=1: 100 ;(\triangle)$, unmodified cellulose; $(x)$, sodium metaperiodate-oxidized cellulose; (O), $\mathrm{K}_{2} \mathrm{Cr}_{2} \mathrm{O}_{7}$-oxalic acid-oxidized cellulose; ( $\mathrm{O}$ ), $\mathrm{K}_{2} \mathrm{Cr}_{2} \mathrm{O}_{7}-\mathrm{H}_{2} \mathrm{SO}_{4}$-oxidized cellulose.

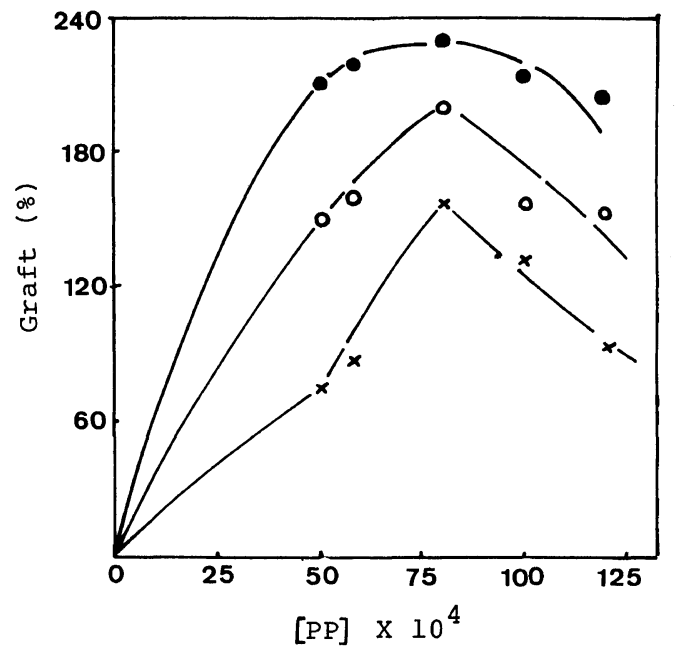

Figure 2. Dependence of $\%$ graft uptake on [peroxydiphosphate]: [MMA], $46.94 \times 10^{-2} \mathrm{moll}^{-1}$; $\left[\mathrm{H}^{+}\right.$], $0.148 \mathrm{moll}^{-1}$; temp, $70^{\circ} \mathrm{C}$; time, $4 \mathrm{~h} ; \mathrm{M}: \mathrm{L}=1: 100$; $(x)$, sodium metaperiodate-oxidized cellulose; $(\mathrm{O})$, $\mathrm{K}_{2} \mathrm{Cr}_{2} \mathrm{O}_{7}-\mathrm{H}_{2} \mathrm{SO}_{4}$-oxidized cellulose; ( $), \mathrm{K}_{2} \mathrm{Cr}_{2} \mathrm{O}_{7}-$ oxalic acid-oxidized cellulose.

$120 \times 10^{-4} \mathrm{moll}^{-1}$. As is evident, increasing the PP concentration from $50 \times 10^{-4}$ to $80 \times 10^{-4} \mathrm{moll}^{-1}$ is accompanied by a significant increase in the graft uptake. Thereafter grafting decreases.

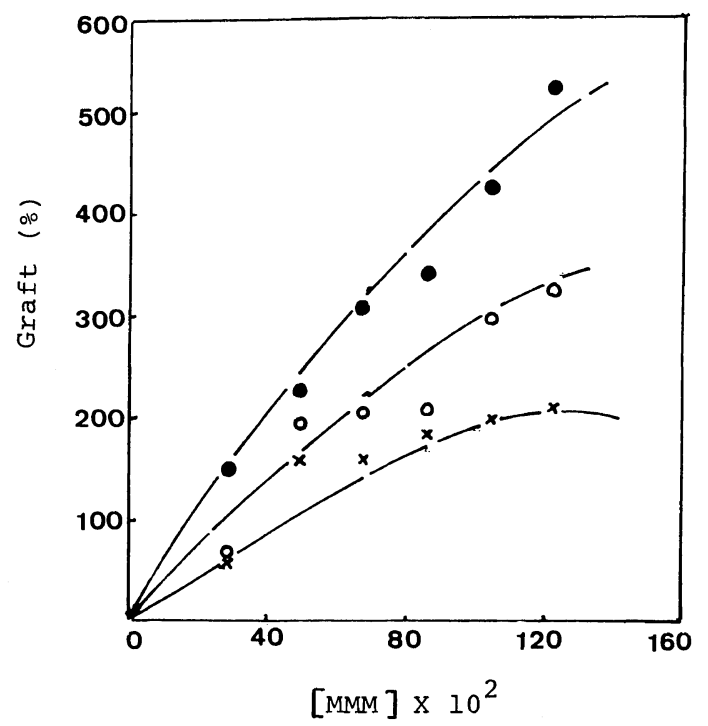

Figure 3. Dependence of $\%$ graft uptake on [MMA]: [PP], $80 \times 10^{-4} \mathrm{moll}^{-1}$; $\left[\mathrm{H}^{+}\right], 0.148 \mathrm{moll}^{-1}$; temp, $70^{\circ} \mathrm{C}$; time, $4 \mathrm{~h} ; \mathrm{M}: \mathrm{L}=1: 100 ;(\times)$, sodium metaperiodateoxidized cellulose; $(\mathrm{O}), \mathrm{K}_{2} \mathrm{Cr}_{2} \mathrm{O}_{7}-\mathrm{H}_{2} \mathrm{SO}_{4}$-oxidized cellulose; (-), $\mathrm{K}_{2} \mathrm{Cr}_{2} \mathrm{O}_{7}$-oxalic acid-oxidized cellulose.

These findings can be explained as follows. ${ }^{24}$ Peroxydiphosphate (PP) decomposes to yield $\mathrm{H}_{2} \mathrm{PO}_{4} \cdot, \cdot \mathrm{OH}, \mathrm{HPO}_{4}^{-} \cdot$ radicals. These free radicals may participate in (a) the direct abstraction of hydrogen from cellulose backbone to bring about cellulose macroradical capable of initiating grafting, and (b) the termination process of the growing polymer chain. At a lower PP concentration the effect of (a) seems to prevail over that of (b), thereby increasing grafting. The opposite holds true at a higher PP concentration where the effect of (b) is more pronounced than (a). As a result, lower grafting occurs.

\section{Dependence of $\%$ Graft Uptake on MMA Concentration}

The rate of grafting was investigated by varying the MMA concentration from $27.98 \times 10^{-2} \mathrm{moll}^{-1}$ to $122.30 \times 10^{-2} \mathrm{moll}^{-1}$. The results are shown in Figure 3. The $\%$ graft uptake increase with increasing monomer concentration. ${ }^{24,25}$ In its shown that monomer participates in the grafting process. The increase in graft yield with an increase in monomer concentration might be due to (a) complexation of cellulose with monomer to enhance 


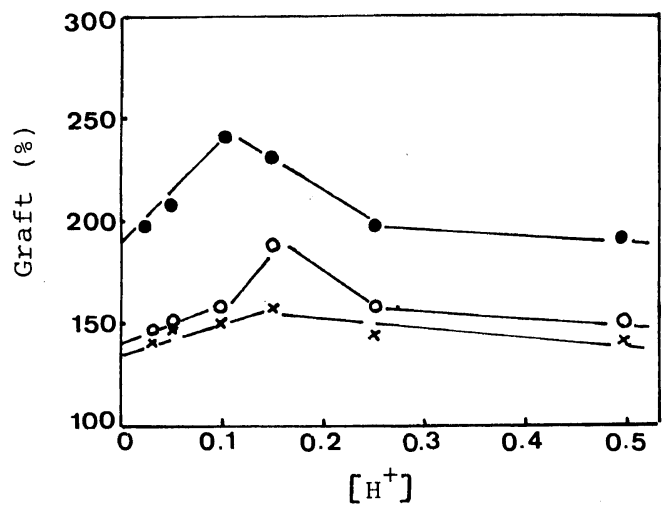

Figure 4. Dependence of $\%$ graft uptake on $\left[\mathrm{H}_{2} \mathrm{SO}_{4}\right]$ : [PP], $80 \times 10^{-4} \mathrm{moll}^{-1}$; [MMA], $46.94 \times 10^{-2} \mathrm{moll}^{-1}$; temp, $70^{\circ} \mathrm{C}$; time, $4 \mathrm{~h} ; \mathrm{M}: \mathrm{L}=1: 100 ;(\times)$, sodium metaperiodate-oxidized cellulose; (O), $\mathrm{K}_{2} \mathrm{Cr}_{2} \mathrm{O}_{7}-$ $\mathrm{H}_{2} \mathrm{SO}_{4}$-oxidized cellulose; (O), $\mathrm{K}_{2} \mathrm{Cr}_{2} \mathrm{O}_{7}$-oxalic acidoxidized cellulose.

its reactivity, thereby increasing graft percent, (b) the formation of some type of charge-transfer complex with the oxidant which favours grafting, (c) the swelling of the cellulose thus facilitates the diffusing of monomer to growing chains and active sites on the cellulose, so that grafting is enhanced.

\section{Dependence of $\%$ Graft Uptake on $\mathrm{H}_{2} \mathrm{SO}_{4}$ Concentration}

The increase in acid concentration from 0 to $0.0148 \mathrm{moll}^{-1}$ increases the percentage of grafting and with a further increase in the acid concentration, the graft yield decreases (Figure 4).

Edward $^{33,34}$ and Siglla $^{35}$ predicted that the reaction of peroxide is subject to acid catalysis. Hence, it is assumed that the reactions of peroxydiphosphate, both a peroxide and an oxyanion, i.e., oxyanion derivative of $\mathrm{H}-\mathrm{O}-\mathrm{O}-\mathrm{H}$ are strongly subject to acid catalysis. Peroxydiphosphate, $\mathrm{P}_{2} \mathrm{O}_{8}^{4-}$ is highly protonated in acid medium due to its high negative charge. The various species are $\mathrm{P}_{2} \mathrm{O}_{8}^{4-}$, $\mathrm{H}_{2} \mathrm{P}_{2} \mathrm{O}_{8}^{3-}, \mathrm{H}_{2} \mathrm{P}_{2} \mathrm{O}_{8}^{2-}, \mathrm{H}_{3} \mathrm{P}_{2} \mathrm{O}_{8}^{-}$, and $\mathrm{H}_{4} \mathrm{P}_{2} \mathrm{O}_{8}$. The concentration of these species are pH-dependent. ${ }^{36}$. The species involving the protonation of peroxydic oxygen, $\mathrm{H}_{5} \mathrm{P}_{2} \mathrm{O}_{8}^{+}$may also be present. Santappa and coworkers ${ }^{32,37}$ suggested that the concentration of $\mathrm{H}_{3} \mathrm{P}_{2} \mathrm{O}_{8}^{-}$increases with increasing $\left[\mathrm{H}^{+}\right]$. In the lower range of acid concentration, i.e., up to 0.148 moll $1^{-1}$, the most active species, $\mathrm{H}_{3} \mathrm{P}_{2} \mathrm{O}_{8}^{-}$might be

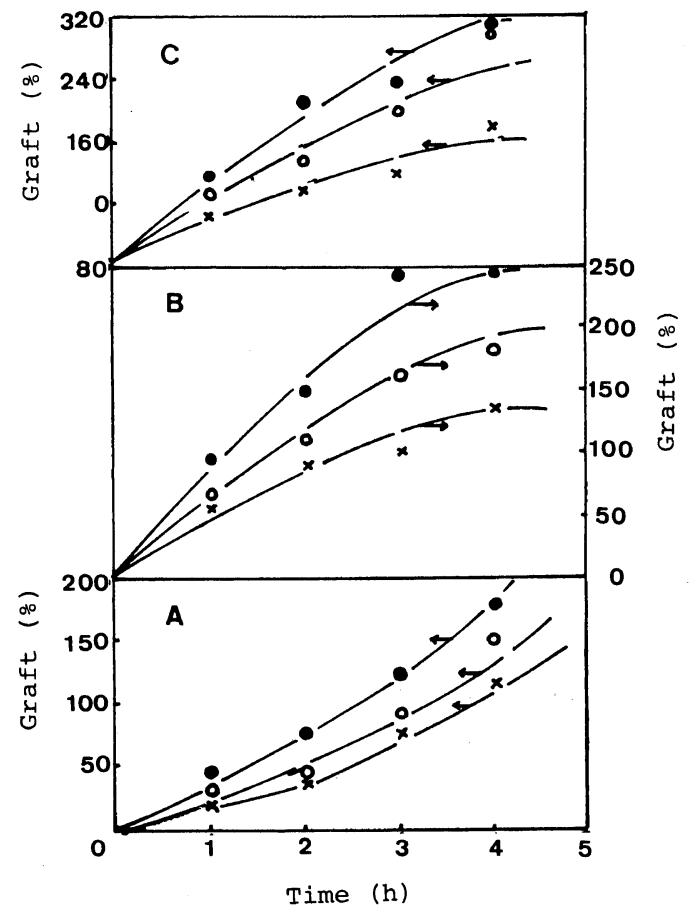

Figure 5. Dependence of $\%$ graft uptake on reaction temperature: [PP], $80 \times 10^{-4} \mathrm{moll}^{-1}$; [MMA], $46.94 \times 10^{-2} \mathrm{moll}^{-1} ;\left[\mathrm{H}^{+}\right], 0.148 \mathrm{moll}^{-1} ; \mathrm{M}: \mathrm{L}=1: 100$; A, periodate-oxidized cellulose; $\mathrm{B}, \mathrm{K}_{2} \mathrm{Cr}_{2} \mathrm{O}_{7}-\mathrm{H}_{2} \mathrm{SO}_{4}$ oxidized cellulose; $\mathrm{C}, \mathrm{K}_{2} \mathrm{Cr}_{2} \mathrm{O}_{7}$-oxalic acid-oxidized cellulose; $(\times)$, temp, $65^{\circ} \mathrm{C} ;(\bigcirc)$, temp, $70^{\circ} \mathrm{C} ;(\bigcirc)$, temp, $75^{\circ} \mathrm{C}$.

formed giving rise to a multitude of free radicals and thus enhance grafting. Beyond $0.148 \mathrm{moll}^{-1}$ of acid concentation, the formation of less active species dominates, thereby decreasing the graft yield.

\section{Dependence of $\%$ Graft Uptake on Reaction Temperature}

Figure 5 shows the effect of temperature on the grafting of MMA onto sodium metaperiodateoxidized cellulose, potassium dichromate-sulphuric acid-oxidized cellulose, and potassium dichromateoxalic acid-oxidized cellulose. In each case, the graft yield follows the order $75^{\circ} \mathrm{C}>70^{\circ} \mathrm{C}>65^{\circ} \mathrm{C}$. The dependence of the rate of grafting with an increase in temperature may be ascribed to the greater activation energy. The swellability of the cellulosic material and the monomer diffusion rates are enhanced by increasing the reaction temperature, thereby causing the graft yield to increase. 
Table I.

\begin{tabular}{|c|c|c|c|c|c|c|}
\hline \multirow{2}{*}{ Solvent } & \multicolumn{2}{|c|}{$\begin{array}{l}\text { Periodate-oxidized } \\
\text { cellulose }\end{array}$} & \multicolumn{2}{|c|}{$\begin{array}{l}\mathrm{K}_{2} \mathrm{Cr}_{2} \mathrm{O}_{7}-\mathrm{H}_{2} \mathrm{SO}_{4}^{-} \\
\text {oxidized cellulose }\end{array}$} & \multicolumn{2}{|c|}{$\begin{array}{l}\mathrm{K}_{2} \mathrm{Cr}_{2} \mathrm{O}_{7} \text {-oxalic } \\
\text { acid-oxidized cellulose }\end{array}$} \\
\hline & $\%$ Graft & $\%$ Homopolymer & $\%$ Graft & $\%$ Homopolymer & $\%$ Graft & $\%$ Homopolymer \\
\hline Methanol & 187.3 & 25.8 & 265.9 & 22.1 & 309.6 & 13.3 \\
\hline Ethanol & 98.0 & 28.9 & 205.1 & 23.4 & 227.6 & 21.4 \\
\hline Isopropyl alcohol & 82.2 & 34.1 & 97.3 & 30.2 & 117.5 & 27.6 \\
\hline Isobutyl alcohol & 15.3 & 50.3 & 41.5 & 38.8 & $58 . \dot{0}$ & 34.5 \\
\hline Isoamyl alcohol & 7.5 & 59.7 & 20.0 & 41.7 & 22.6 & 39.6 \\
\hline
\end{tabular}

\section{Effect of Solvent on Graft Yield}

The grafting reaction was conducted with, $[P P]=80 \times 10^{-4} \mathrm{moll}^{-1}, \quad[\mathrm{MMA}]=46.94 \times 10^{-2}$ $\mathrm{moll}^{-1},[\mathrm{H}]=0.148 \mathrm{moll}^{-1} ; \mathrm{M}: \mathrm{L}=1: 100$; temp, $70^{\circ} \mathrm{C}$; time, $4 \mathrm{~h}$; solvent, $25 \%$ in presence of alcoholic solvents. The $\%$ graft and $\%$ homopolymer are arranged in Table I.

The decrease in graft yield from methanol to isoamyl alcohol is due to the increase in \% homopolymer formation, a decrease in the ability of swelling of cellulosic material, and the difference in capability of these solvent as terminator for the graft-polymer radical and the cellulose macroradical.

\section{Molecular-Weight Determination}

The weight-average molecular weight $M_{w}$ of the separated poly(methyl methacrylate) from grafted oxidized cellulose was estimated (Table II). The results indicate that the $M_{w}$ increases with increasing percentage of grafting in the case of sodium metaperiodate-oxidized cellulose and $\mathrm{K}_{2} \mathrm{Cr}_{2} \mathrm{O}_{7}-$ oxalic acid-oxidized cellulose; the reverse holds good in the case of $\mathrm{K}_{2} \mathrm{Cr}_{2} \mathrm{O}_{7}-\mathrm{H}_{2} \mathrm{SO}_{4}$-oxidized cellulose.

Acknowledgement. We are grateful to Department of Chemistry, Ravenshaw College, Cuttack where this work was carried out.

\section{REFERENCES}

1. J. W. Vanderhoff, in "Vinyl Polymerization," Part II, G. E. Ham, Ed., Dekker, N.Y., 1969, Chapter 1.

2. M. Negishi, K. Arai, and S. Okada, J. Appl. Polym. Sci., 11, 115 (1967).

3. M. Negishi, K. Arai, and S. Okada, J. Appl. Polym. Sci., 12, 2585 (1968).
Table II.

\begin{tabular}{lccc}
\hline Nature of substrate & $\%$ Graft & $M_{w} \times 10^{-5}$ & $\overline{D P} \times 10^{-3 a}$ \\
\hline $\begin{array}{l}\text { Sodium metaperio- } \\
\text { date-oxidized }\end{array}$ & 129.95 & 17.12 & 17.12 \\
cellulose & 156.75 & 18.83 & 18.83 \\
& 174.55 & 20.55 & 20.55 \\
$\mathrm{~K}_{2} \mathrm{Cr}_{2} \mathrm{O}_{7}$-oxalic & 184.1 & 15.83 & 15.83 \\
acid-oxidized & 206.4 & 18.82 & 18.82 \\
cellulose & 227.1 & 20.21 & 20.21 \\
& & & \\
$\mathrm{~K}_{2} \mathrm{Cr}_{2} \mathrm{O}_{7}-\mathrm{H}_{2} \mathrm{SO}_{4}^{-}$ & 109.1 & 11.41 & 11.41 \\
oxidized & 155.95 & 9.03 & 9.03 \\
cellulose & 199.5 & 7.05 & 7.05 \\
\hline
\end{tabular}

a $\overline{D P}$, degree of polymerization.

4. K. Arai, M. Negishi, T. Suda, and K. Doi, J. Polym. Sci., A-1, 9, 1879 (1971).

5. D. A. House, Chem. Rev., 62, 185 (1962).

6. W. K. Wilmarth and A. Him, "Peroxide Reaction Chem., 5, 1858 (1966). 1962, p 175.

7. Y. Ikada, Y. Nishizaki, and I. Sakurada, J. Polym. Sci., Polym. Chem. Ed., 12, 1829 (1974).

8. A. A. Green, J. O. Edwards, and P. Jones, Inorg. Chem. 5, 1858 (1966).

9. M. Anderson, J. O. Edwards, A. A. Green, and M. D. Wiswell, Inorg. Chem. Acta, 3, 655 (1969).

10. R. J. Lussier, W. M. Risen, and J. O. Edwards, J. Phys. Chem., 74, 4039 (1970).

11. E. Chaffee, I. I. Creaser, and J. O. Edwards, Inorg. Nucl. Chem. Lett., 7, 1 (1971).

12. J. O. Edwards, Coord. Chem. Rev., 8, 87 (1972).

13. S. S. Hariharan and A. Meenakshi, J. Polym. Sci., Polym. Lett. Ed., 15, 1 (1977).

14. K. Dimov and P. Pavlov, J. Polym. Sci., A-1, 7, 2775 (1969).

15. D. H. Gallagher, Text. Res. J., 40, 621 (1970).

16. R. J. Dement, J. C. Arther, Jr., and W. F. McSherry, Text. Res. J., 31, 821 (1961). 
17. A. Kantouch, A. Hebeish, and M. H. El-Rafie, Eur. Polym. J., 6, 1575 (1970)

18. A. Hebeish, A. Kantouch, and M. H. El-Rafie, $J$. Appl. Polym. Sci., 15, 1921 (1971).

19. A. Hebeish, A. Kantouch, and M. H. El-Rafie, J. Appl. Polym. Sci., 15, 11 (1971).

20. A. Kantouch, A. Hebeish, and M. H. El-Rafie, Text. Res. J., 42, 10 (1972).

21. Y. Ogiwara and H. Kubcta, J. Appl. Polym. Sci., 17, 2427 (1973).

22. M. Kamel, A. Hebeish, and A. Al-Aref, J. Appl. Polym. Sci., 18, 3463 (1974).

23. A. Hebeish, M. H. El-Rafie, M. I. Khalil, and A. Bendak, J. Appl. Polym. Sci., 21, 1901 (1977).

24. P. L. Nayak, S. Lenka, and M. K. Mishra, J. Appl. Polym. Sci., 25, 63 (1980).

25. P. L. Nayak, S. Lenka, and M. K. Mishra, to be published in Angew. Makromol. Chem., No. 1371.

26. S. Lenka, P. L. Nayak, and M. K. Mishra, Angew. Makromol. Chem., 84, 183 (1980).
27. P. L. Nayak, S. Lenka, and M. K. Mishra, to be published in J. Polym. Sci.

28. R. J. Valles, M. C. Otizinger, and D. W. Lewis, J. Appl. Polym. Sci., 4, 92 (1960).

29. S. Chinai, A. Resnik, and T. Matlack, J. Polym.Sci., 17, 391 (1955).

30. Y. Iwakura, T. Kurosaki, and Y. Imai, J. Polym. Sci., A, 3, 1185 (1965).

31. Y. Ogiwara, Y. Ogiwara, and H. Kubota, J. Polym. Sci., A-1, 5, 2791 (1967).

32. P. Maruthamuthu and M. Santappa, J. Inorg. Nucl. Chem., 37, 1305 (1975).

33. J. O. Edwards, J. Chem. Educ., 31, 270 (1954).

34. J. O. Edwards, Chem. Rev., 50, 455 (1952).

35. J. J. Siglla, J. Chem. Phys., 788 (1958).

36. M. N. Crutchfield, "Peroxide Reaction Mechanisms," J. O. Edwards, Ed., Interscience, N.Y., 1962, p 41.

37. P. Maruthamuthu and M. Santappa, Indian J. Chem., 14A, 35 (1976). 